\title{
MEIGS' SYNDROME ASSOCIATED WITH ELEVATED CA 125 LEVEL - A RARE CASE
}

GHANI T ${ }^{1}$, SULTANA N ${ }^{2}$, HUSSAIN T $^{3}$, BEGUM A ${ }^{4}$, PAUL SK ${ }^{5}$, NOORJAHAN ${ }^{6}$, HOSSAIN MS $^{7}$

\begin{abstract}
Meigs' syndrome is a rare but well known syndrome. It is a triad of ovarian fibroma with ascites and pleural effusion that resolves after resection of the tumour. Postmenopausal women with solid adnexal masses, ascites and pleural effusion with elevated CA125 level are highly suggestive for malignant ovarian tumour. Only few cases of Meigs, syndrome with elevated CA 125 have been reported in different literatures. Here we report a case of Meigs syndrome due to right sided ovarian fibroma with elevated CA 125 level in postmenopausal woman.
\end{abstract}

J Dhaka Med Coll. 2015; 24(1) : 76-78.

\section{Introduction}

Meigs' syndrome is a triad of benign ovarian tumour (fibroma), ascites and pleural effusion which resolves after removal of the tumour. ${ }^{1}$ Meigs' syndrome with an elevated CA 125 level has been reported. ${ }^{2}$ Although Meigs' syndrome mimics a malignant condition especially in postmenopausal women with raised CA 125 level, it is a benign disease and has a very good prognosis. CA 125 level also returns to normal levels after surgery. Life expectancy after surgical removal of the tumour is the same as in the general population. ${ }^{3}$

\section{Case Report}

A 50 years old postmenopausal woman was admitted in Dhaka Medical College Hospital, Dhaka, on $8^{\text {th }}$ January, 2015 with the complaints of lump in lower abdomen for 3-4 years with pain for 10 days. She was treated conservatively in surgery department for 4 days. Then she was transfered toGynae department asultrasographic reportshowed a fairly large hypoechoic masspredominently solid with small cystic component in right adnexal region causing compression of right ureter resulting right sided hydronephrosisand mild ascites. Her serum CA 125 level was found $355.1 \mathrm{U} / \mathrm{ml}$.

On General Examination she was mildly anaemic. On abdominal examination a mass felt in lower abdomen in hypogastric region and extending to right iliac fossa about $10 \mathrm{~cm} \times 8$ $\mathrm{cm}$, mobile, nodular surface, hard in consistency, tender, ill-defined margin. Bimanual examination uterus not separately delineated, a mass felt through right fornix.

Complete blood count report showed a high ESR $40 \mathrm{~mm}$ in $1^{\text {st }}$ hour. Tuberculin test found negative. Chest $\mathrm{x}$-Ray showed normal study. CT scan of whole abdomen showed large abdominopelvic mass of $144 \mathrm{~mm} \times 88 \mathrm{~mm}$ possibly of ovarian origin and IVU report revealed normal excretory function of both kidneys and capacious right renal

1. Dr. Tabassum Ghani, Assistant Professor, Department of Obstetrics \& Gynaecology, Dhaka Medical College, Dhaka.

2. Dr. Nilufar Sultana, Professor, Department of Obstetrics \& Gynaecology, Dhaka Medical College, Dhaka.

3. Dr. Taufiqua Hussain, Associate Professor, Department of Obstetrics \& Gynaecology, Dhaka Medical College, Dhaka.

4. Dr. Afrina Begum, Associate Professor, Department of Obstetrics \& Gynaecology, Dhaka Medical College, Dhaka.

5. Dr. Subinoy Krisno Paul, Assistant Professor, Department of Surgery, Dhaka Medical College, Dhaka.

6. Dr. Noorjahan, Consultant, Department of Obstetrics \& Gynaecology, Dhaka Medical College Hospital, Dhaka.

7. Dr. Md. Sakhawat Hossain, Lecturer, Department of Biochemistry, Sir Salimulah Medical College, Gazipur Correspondence: Dr. Tabassum Ghani, Assistant Professor, Department of Obstetrics \& Gynaecology, Dhaka Medical College, Dhaka. 
pelvis.Serum creatinine level was normal. SGPT was found $66.5 \mathrm{U} / \mathrm{L}$.

When these investigations were being done, thepatient's condition was gradually deteriorating. She developed abdominal distension with breathing difficulty. Chest $\mathrm{x}-$ ray showed right sided pleural effusion and ultrasonography foundmoderate ascites. Ascitic tap fluid cytology revealed no malignant cells. A preoperative diagnosis of ovarian malignancy was made and patient was prepared for exploratory laparotomy.

Laparotomy was done by right paramedian incision, clear ascitic fluid about 2 litres was drained out. There was a solid right ovarian tumour of $14 \mathrm{~cm} \times 16 \mathrm{~cm}$ with intact capsule and left ovary and uterus found normal. No metastatic deposit in omentum, peritoneum and surface of other abdominal organs. Lymph nodes were not palpable. Total abdominal hysterectomy with bilateral salpingoophorectomy with infracolicomentectomy was done.

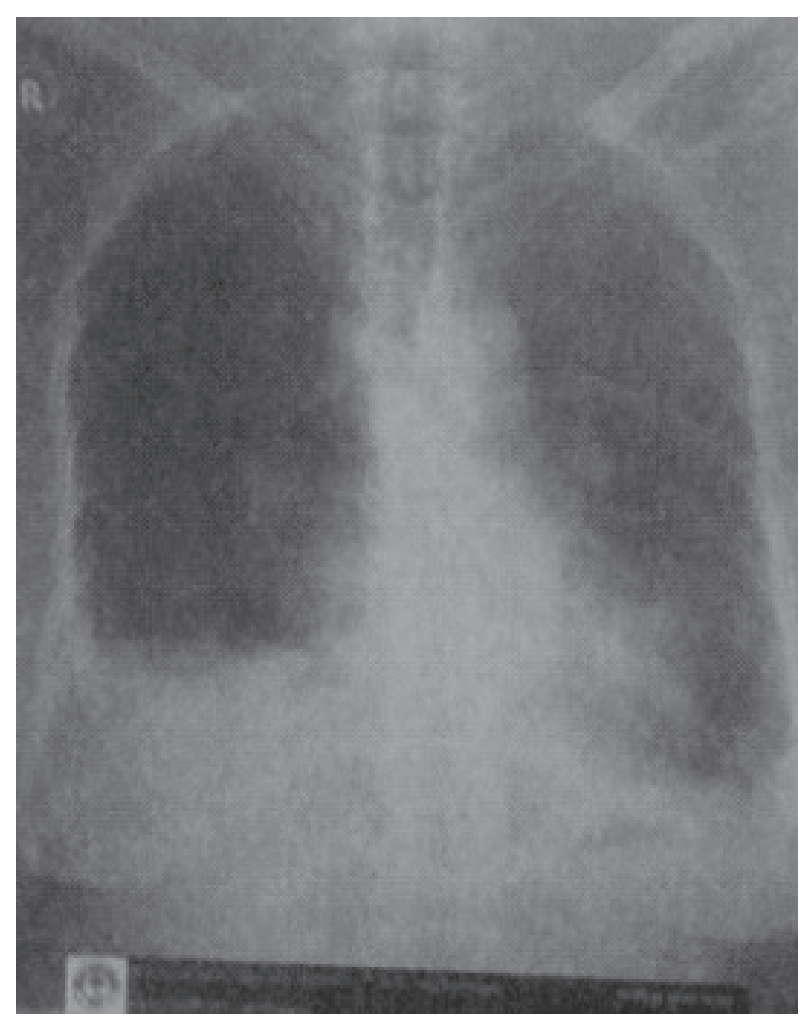

Fig.-1: Right Sided pleural effusion.

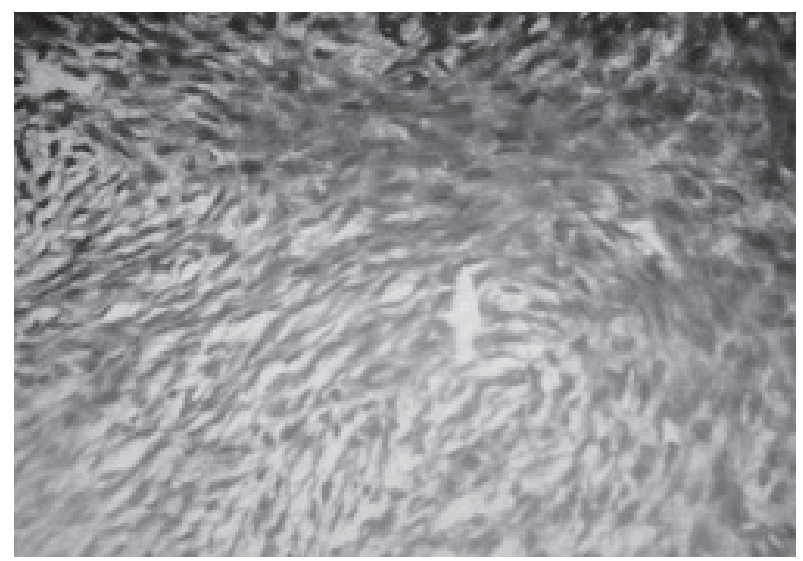

Fig.-2: Microscopic appearance of right ovarian fibroma.

On cut section, Solid area with yellowish tinge with some brown colouredcystic changes was found. Histopathology revealed ovarian fibroma and absence of malignant cells. Postoperative period was uneventful. Pleural effusion regressed which was evidenced by radiograph 2 weeks after surgery. Her SGPT level comes to normal $40.2 \mathrm{U} / \mathrm{L}$ on $9^{\text {th }}$ postoperative day. She was discharged on $15^{\text {th }}$ postoperative day. She is on regular follow up and is asymptomatic. The serum CA 125 level on the $30^{\text {th }}$ day after operation was $21 \mathrm{IU} / \mathrm{ml}$.

\section{Discussion}

Salmon, in 1934, described the association of pleural effusion with benign pelvic tumours. In 1937,Meigs' and Cass described 7 cases of ovarian fibroma with ascites and pleural effusion that resolve after removal of tumour. ${ }^{1}$ Ovarian fibroma is found in $2-5 \%$ of surgically removed ovarian tumours and Meigs' syndrome is observed in about $1 \% .{ }^{4}$ Meigs' suggested that irritation of the peritoneal surfaces by ovarian tumuor stimulates the production of peritoneal fluid. Pleural effusion is thought secondary to the passage of ascitic fluid to pleural space through diaphragm or diaphragmatic lymphatic vessels or alternatively because of congenital defects, which are more common on right side. ${ }^{5} \mathrm{CA} 125$ antigen is a glycoprotein expressed in the embryonic coelomic epithelium. This antigen can also appear in many adult tissues such as the epithelium of fallopian tubes, endometrium, endocervix and ovaries. ${ }^{6} \mathrm{CA} 125$ is generally elevated in 
patients mostly with malignant epithelial ovarian tumour. It can be elevated in some benign disorders such as endometriosis, pelvic inflammatory disease and uterine leiomyoma. It can also increase in pericardial, pleural and peritoneal irritation or inflammation. ${ }^{7}$ The coincidence of Meigs' syndrome with elevation of serum 125 levels has been described in published literature in only 28 cases among them 15 cases were ovarian fibroma. ${ }^{2}$ As CA 125 level positive for ovarian malignancy, laparotomy and histopathological examination are required for the correct diagnosis and treatment. ${ }^{8}$ CA 125 level comes to normal after resection of tumour after a variable period of time.

\section{Conclusion}

This report emphasizes that benign gynaecological conditions may mimic clinical, ultrasonographic and biochemical sign suggestive of malignancy producing diagnostic dilemma. They rarely considered as the benign disease in differential diagnosis when patient presented with ascites and pleural effusions with negative cytological examination. However, a small percentage of patients with Meigs' syndrome can present with raised serum CA 125 level.

\section{References}

1. Meigs JV, Class JW. Fibroma of the ovary with ascites and hydrothorax, with a report of seven cases. Am JObstetGynecol 1937; 33: 249-67.

2. Timmerman D, Moreman P, Vergote I. Meigs' syndrome with elevated CA 125: 2 cases and review of the literature. GynecolOncol1995; 59 : 405-8.

3. Lin JY, Angel C, Sickel JZ. Megs' syndrome with elevated serum CA 125. ObstetGynecol 1992; 80(3pt 2): 563-6.

4. Scully RE. Ovarian tumors: a review. Am J Pathol 1977; 87(3): 686-720.

5. AgranoffD, May D, Jameson C, Knowles GK. Pleural effusion and a pelvic mass. Postgrad Med J 1998; 74(871): 265-7.

6. Kabawat SE, Bast RC Jr, Bhan AK, Welch WR, Knapp RC, Colvin RB. Tissue distribution of a coelomic-epithelium-related antigen recognized by the monoclonal antibody OC125. Int J Gynecol Pathol 1983; 2: 275-85.

7. Niloff JM, Knapp RC, Schaetzl E, Reynolds C, Bast RC.CA 125 antigen levels in obstetric and gynaecologic patients. Obstet Gynecol 1984; 64(5):703-7.

8. Abad A, Cazorla E, Ruiz F, et al. Meigs' syndrome with elevated CA 125: case report and review of the literature. Eur J Obstet Gynecol Reprod Biol 1999; 82(1):97-9. 